\title{
Rock thermal conductivity of Mesozoic geothermal aquifers in the Northeast German Basin
}

Sven Fuchs*, Andrea Förster

GFZ German Research Centre for Geosciences, Section 4.1Reservoir Technologies, Telegrafenberg, 14473 Potsdam, Germany

* Corresponding author. Tel.: +49 33128828 42; fax: +49 33128814 50. E-mail address: fuchs@gfzpotsdam.de (S. Fuchs). 


\begin{abstract}
This study reports laboratory-measured thermal-conductivity values of Mesozoic sandstones from eight wells (predominantly geothermal boreholes) of the Northeast German Basin (NEGB). The measurements were made on drill core using the optical scanning method. Bulk thermal conductivities of sandstones corrected for in situ thermal conditions range between 2.1 and $3.9 \mathrm{~W} / \mathrm{m} / \mathrm{K}$. In general, the Mesozoic sandstones show a large effective porosity typically ranging between $16 \%$ and $30 \%$. Matrix thermal conductivity ranges from 3.4 to 7.4 $\mathrm{W} / \mathrm{m} / \mathrm{K}$. The higher values reflect the large quartz content in sandstone. Based on the in situ thermal conductivity and corresponding interval temperature gradient, obtained from highprecision temperature logs measured under thermal borehole equilibrium, interval heat-flow values were computed in the Middle Buntsandstein section (between 1400 and $1500 \mathrm{~m}$ ) of two boreholes located in the Stralsund area. The heat flow averages to $74 \mathrm{~mW} / \mathrm{m}^{2}$ (Gt Ss 1/85 borehole) and $78 \mathrm{~mW} / \mathrm{m}^{2}$ (Gt Ss 2/85 borehole) and, by adding a heat-flow component of 1.8 $\mathrm{mW} / \mathrm{m}^{2}$ for the heat production in the overburden, are in good correspondence with previously reported surface heat flow of $77 \mathrm{~mW} / \mathrm{m}^{2}$. Based on these values and the temperature $\log$ information, thermal conductivity was indirectly calculated for entire borehole profiles. The discrepancy between laboratory measured and computed thermal conductivities in the two boreholes is in the order of $0.24 \mathrm{~W} / \mathrm{m} / \mathrm{K}$ and $0.56 \mathrm{~W} / \mathrm{m} / \mathrm{K}$. Formation in situ thermal conductivity of the Mesozoic section ranges between 1.5 and $3.1 \mathrm{~W} / \mathrm{m} / \mathrm{K}$.
\end{abstract}

Keywords: Thermal conductivity; Porosity; Heat flow; Geothermal aquifers; North German Basin 


\section{Introduction}

The thermal conductivity of rocks is a major physical property for the study of the Earth's thermal field. It is a basic parameter required to determine heat flow $(q)$, which, according to Fourier's law of heat conduction (1), is given by the product of temperature gradient $(\delta T / \delta z)$ and the apparant thermal conductivity $(\lambda)$ in a depth interval $(z)$.

$$
q=-\lambda \delta T / \delta \mathbf{z}
$$

Knowledge of the surface heat-flow $\left(\mathrm{q}_{\mathrm{s}}\right)$ value provides insight into the heat potential from depth and allows inferences for the deep geothermal situation of an area beyond depths encountered by boreholes.

Additionally, the thermal properties of sedimentary formations are first-order controls on the thermal structure of basins and can be used to determine geothermal targets on regional and local scale. In areas previously explored for geo-resources such as the Northeast German Basin (NEGB), numerous boreholes provide essential data sources for thermal field exploration. Borehole temperature measurements, either as single-point temperature recordings or as continuous temperature logs (Förster, 2001), form basic data on the subsurface temperature conditions. In contrast, borehole core samples, on which thermal conductivity $(\lambda)$ could be measured, are scarce and limited to the targets of specialized exploration. For example, previous studies in the NEGB on the $\lambda$ parameter concentrated on the measurement of core from Permian and Permo-Carboniferous formations (Norden and Förster, 2006) forming the basis for a study on surface heat flow (Norden et al., 2008). For the Mesozoic and Cenozoic sections practically no data are available up to now.

Research conducted in the framework of the GeoEnergy Program (this issue) fills this gap by providing new $\lambda$ data for the Mesozoic sections. These sections host important geothermal aquifers recently explored by core and modern well log analysis allowing the development of a combined use of these data. Thus a method is sought, which overcomes the limiting factor

of point information on $\lambda$ from core measurement alone and provides continuous $\lambda$-profiles for large depth sections using standard geophysical wireline logs. 
The expected results are important influential parameters for other GeoEnergy research (this issue), for example in the modeling of thermal maturation of organic matter implemented in time-temperature basin modeling for hydrocarbon research or in combining geological structure and thermal properties for a quantification of the subsurface thermal structure on which the future utilization of geothermal energy is based.

The approach being developed and applied to the NEGB data uses multivariate statistics to determine $\lambda$ based on a statistical function employing data from gamma-ray, neutron, density, and temperature logs. Additionally, $\lambda$ will be determined indirectly from the major mineral constituents (derived from XRD analyses) and their thermal-conductivity values using different approaches described in the international literature. Comparing the results of these different approaches will provide an important insight into the potential error made by indirectly determining $\lambda$ in basin analysis.

In this paper, a first set of laboratory measurements of thermal conductivity is reported, which, later on, will be used to verify the statistical approach being part of ongoing research. The paper also contains for a subset of measured laboratory data a comparison with $\lambda$ values calculated from mineral constituents and rock porosity. In addition, the laboratory data for different depth intervals are related to the respective interval temperature gradient, calculated from high-resolution, continuous temperature logs, allowing the calculation of an average heat flow for a borehole location. In turn, the this heat-flow value and the interval temperature gradient then are used to indirectly determine $\lambda$ for those formations for which there is no drill core control.

Figure 1 shows the study area in Mecklenburg-Vorpommern, in which eight wells ${ }^{1}$ are investigated: the Gt Ss 1/85 and Gt Ss 2/85 boreholes located near the city of Stralsund at the northern margin of the NEGB; the Dp N 1/82, Gt N 2/85, and Gt N 3/86 boreholes near the city of Neubrandenburg and the Gt S 2/87, Gt S 3/87 and Gt S 5/87) boreholes near the city of Schwerin in the western part of the NEGB.

\footnotetext{
${ }^{1}$ Gt: geothermal exploration well; Dp: disposal exploration well
} 


\section{Geological background}

The NEGB is a sub-basin of the Central European Basin system containing Cenozoic, Mesozoic, and Upper Paleozoic (Permian and Carboniferous) sediments that are up to $12 \mathrm{~km}$ thick (Hoth et al., 1993). Since the 1960s, a large number of wells were drilled in the sedimentary succession of the NEGB as part of an exploration for oil and gas and geothermal energy. Analyses of drill cores, geophysical well logs, and hydraulic tests, performed in many of these wells formed the basis for a sound understanding of the geology and physical properties of the major reservoirs in this region. In recent years, the Mesozoic aquifers, predominantly made up of sandstones (Fig. 2), were studied for their lithological, mineralogical, petrophysical, and hydrogeological signatures (Feldrappe et al., 2008; Wolfgramm et al., 2008).

In this paper, the thermal conductivity of the Mesozoic sandstone aquifer section is investigated, comprising the Aalenian (Dogger- $\beta$ ) (youngest) and the Detfurth Formation (Middle Buntsandstein) (oldest) (cf. Fig. 2).

The occurrence of the Aalenian (Dogger- $\beta$, Altmark) sandstone is limited to the southwestern area of Mecklenburg-Vorpommern. Its thickness is variable (15 - $92 \mathrm{~m}$; Wolfgramm et. al, 2008). Greatest thickness of about $80 \mathrm{~m}$ is observed in a well in the Schwerin area; the sandstone thins out farther to the north and the northeast. The base of the sandstone formation rests at depths between $100 \mathrm{~m}$ near the margins and $2400 \mathrm{~m}$ in some rim synclines in the centre of the NEGB (Feldrappe et al., 2008). The sandstone is medium to fine-grained, and typical porosities are in the range of $21-28 \%$ (Wolfgramm et. al, 2008).

The poorly cemented sandstones of the Rhaetian-Lias aquifer complex occur in most parts of Mecklenburg-Vorpommern (except of the northern Rügen area) and show maximum thicknesses in the south, near to the centre of the NEGB. The thickness of the Lias is in the range of $270-400 \mathrm{~m}$. The base of the Lias rests between depths of $100-2800 \mathrm{~m}$ (Feldrappe et al., 2008). The Lias is subdivided into three formations: the Pliensbachian (fine-grained sandstones), Sinemurian (fine-grained sandstones) and Hettangian consisting of sandstones, siltstones, and claystones. The Hettangian shows thicknesses ranging from 6 - $95 \mathrm{~m}$ (average $46 \mathrm{~m}$ ) and porosities between $19-36 \%$ (average $26 \%$; Wolfgramm et al., 2008). The Rhaetian is between 50 and 250 m thick (Feldrappe et al., 2008). It is subdivided into the 
Triletes, the Contorta, and the Postera consisting of mature sandstones and claystones. The Postera is made up predominantly of sandstone and has a thickness of 12 - $40 \mathrm{~m}$ (average of $30 \mathrm{~m}$ ), whereas the Contorta is pelitic and has thicknesses between 6 and $54 \mathrm{~m}$ (average of 12 m) (Wolfgramm et al., 2008). For both formations typical porosities are in the range of 20 $25 \%$ (Feldrappe et al., 2008).

The fine to medium-grained sandstone of the Stuttgart Formation occurs in most parts of the NEGB (except of Rügen and Altmark areas) and shows a laterally and vertically alternating facies. Mudstones of the flood-plain facies alternate with fluvial channel deposits of variable thickness (Förster et al., 2006 and references therein). The base of the formation lies between depths of 400 - $2500 \mathrm{~m}$ in Mecklenburg-Vorpommern; the thickness of the formation varies between 80 and $100 \mathrm{~m}$ (Feldrappe et al., 2008). Typical porosities of the channel sandstones are 20 - 36 \% (Wolfgramm et al., 2008 and references therein).

The limnic and marine sediments of the Middle Buntsandstein are widespread in the northern part of the NEGB. They are medium-grained and have a thickness of about $180 \mathrm{~m}$ near the city of Stralsund and a maximum thickness of about $500 \mathrm{~m}$ in the basin centre. The base of the Middle Buntsandstein rests at a depth of about $1000 \mathrm{~m}$ near the Baltic coast and at about $3500 \mathrm{~m}$ in the basin centre (Feldrappe et al., 2008). The Middle Buntsandstein group is subdivided into four formations. The Solling Formation on top is mostly composed of two 12 - 20-m-thick sandstone layers, separated by a 20-m-thick claystone. The Hardegsen Formation consists of a basal sandstone (20 - $50 \mathrm{~m}$ thick) and is overlain by siltstones and claystones, with some anhydrite. The Detfurth Formation is made up of sandstones (5 - $40 \mathrm{~m}$ thick) interbedded by siltstones and claystones. The Volpriehausen Formation consists of only poorly cemented sandstone ( 2 - $10 \mathrm{~m}$ thick). The Middle Buntsandstein shows an average sandstone porosity of about 20 - $30 \%$ (Feldrappe et al., 2008).

\section{Methods}

Typical techniques for the measurement of rock thermal conductivity include the divided-bar steady-state technique, the needle-probe transient method (Sass et al., 1971; Sass et al., 1984), and the optical scanning method (Popov et al., 1999). We employed the latter one because of its ease in use allowing a study of large suites of samples in a short time. The optical scanning method is based on scanning a primed and black colored sample surface with a focused and 
continuously operated mobile heat source. The heat source and two infrared temperature sensors (measurement of initial and maximum sample temperature) move with a fixed distance between each other and with the same speed relative to the core sample. The temperature sensor behind the heat source continuously registers the value of the maximum temperature increase along the heating line and yields a continuous conductivity profile. With knowledge of the maximum temperature rise $\Theta$, the heat source power $Q$, the distance $x$ between heat source and temperature sensors and the measurement of a reference standard $\left(\Theta_{S}\right)$ with a known conductivity $\lambda_{S}$, it is possible to determine the thermal conductivity $\lambda$ of each sample along the scanning line. This relation is described by equation (1):

$$
\lambda=\lambda_{\mathrm{s}} \cdot\left(\frac{\Theta_{S}}{\Theta}\right)
$$

Thermal conductivity was measured on core samples both under dry and saturated conditions. For each sample, an average value was computed from at least three scan cycles.

First, the rock samples were dried to constant weight at $60^{\circ} \mathrm{C}$ in a vacuum oven. Later on, the dehydrated samples were saturated by submerging them in distilled water inside of a sealed vacuum exsiccator. Measurements were performed on both a sawed plane $\left(\lambda_{\perp}\right.$; perpendicular to the bedding and in the direction of the vertical heat flow) and on the core mantle ( $\lambda_{\|}$; along the core axis, perpendicular to the principal heat-flow direction). A total of 75 core samples were analyzed. The core diameters varied between 45 and $90 \mathrm{~mm}$, the sample length from $50 \mathrm{~mm}$ to $350 \mathrm{~mm}$. For most of the investigated Mesozoic sediments the bedding was (nearly) parallel to the disk plane.

The effective porosity $(\Phi)$ was determined after the Archimedes method by the mass change between dry (dehydrated at $60{ }^{\circ} \mathrm{C}$ ) and saturated sample.

Bulk $\lambda$ values, measured on saturated samples $\left(\lambda_{\text {sat } M}\right)$, were converted into the matrix thermal conductivity $\left(\lambda_{\text {matrix }}\right)$ using the effective porosity $\Phi$ and the pore medium $\left(\lambda_{\text {pore }}=\lambda_{\text {water }}\right.$ of $0.6 \mathrm{~W} / \mathrm{m} / \mathrm{K})$ according to the geometric mean model (2):

$$
\lambda_{\text {matrix }}^{1-\phi}=\frac{\lambda_{\text {satM }}}{\lambda_{\text {pore }}^{\phi}}
$$


Matrix thermal conductivity also was determined from the $\lambda$ values of the mineral constituents of a particular rock type using the geometric mean model (e.g. Brigaud et. al., 1990) as a mixing law (3)

$$
\lambda_{\text {matrix }}=\prod_{i=1}^{n} \lambda_{i}^{\text {vol }}
$$

where $\lambda_{i}$ is the thermal conductivity of the $i$ th mineral constituent and $\operatorname{vol}_{i}$ is the fractional volume of the mineral constituents. The volumetric fractions of major minerals are obtained from XRD analyses (GTN, 2009, personal communication). The $\lambda$ values of individual minerals are literature values (Horai, 1971; Schön, 1996; cf. Table 2).

High-precision temperature logs (LIAG, 2009) recorded in cm-intervals in borehole thermal equilibrium, were processed for temperature gradients. The temperature gradients were calculated as 1-m running averages and smoothed with an 11-point-mean filter.

\section{Results}

\subsection{Laboratory-measured thermal conductivity}

Table 1 shows the bulk thermal conductivity measured in the direction of principal heat flow on saturated sandstone samples $\left(\lambda_{\text {sat }}\right)$. Values in bold are average values for the different formations. Matrix values were corrected for in situ temperature conditions using borehole temperature data. The correction applied is small $(\max .=0.4 \mathrm{~W} / \mathrm{m} / \mathrm{K})$. The lowest $\lambda$ value of $2.1 \pm 0.11(1-\sigma$ STD $) \mathrm{W} / \mathrm{m} / \mathrm{K}$ is observed in the Stuttgart Formation sandstones $(\mathrm{kmS}$, Keuper) and the highest value of $3.9 \pm 0.27 \mathrm{~W} / \mathrm{m} / \mathrm{K}$ in the Postera sandstone (kOPS, Rhaetian), respectively. The average bulk $\lambda$ values for the Contorta and the Postera sandstones are higher in the Schwerin boreholes $(3.8 \pm 0.18 \mathrm{~W} / \mathrm{m} / \mathrm{K}(\mathrm{kCs})$ and $3.9 \pm 0.08 \mathrm{~W} / \mathrm{m} / \mathrm{K}$ (kOPS)) than in the Neubrandenburg boreholes $(3.3 \pm 0.27 \mathrm{~W} / \mathrm{m} / \mathrm{K}(\mathrm{kCs})$ and $3.4 \pm 0.39$ $\mathrm{W} / \mathrm{m} / \mathrm{K}$ (kOPS)). The Middle Buntsandstein has the largest variation in bulk thermal conductivity of all formations ranging from $2.7 \pm 0.1 \mathrm{~W} / \mathrm{m} / \mathrm{K}$ (smH, Hardegsen, Gt Ss 1/85 borehole) to $3.5 \pm 0.45 \mathrm{~W} / \mathrm{m} / \mathrm{K}$ (smS, Solling, Gt Ss 2/85 borehole) exhibiting a mean value of $3.2 \pm 0.37 \mathrm{~W} / \mathrm{m} / \mathrm{K}$. 
The matrix thermal conductivity (Table 1, column 6), calculated as an average of measurements under saturated and dry conditions, also is lowest for the Stuttgart Formation sandstones (kmS, Middle Keuper) (3.4 $\pm 0.8 \mathrm{~W} / \mathrm{m} / \mathrm{K})$ and highest for the Postera (kOPS) sandstone $(7.4 \pm 0.5 \mathrm{~W} / \mathrm{m} / \mathrm{K})$. The regionally different bulk thermal conductivity observed for the Contorta and the Postera sandstones also is reflected in matrix thermal conductivity. Similarly, the large variation in bulk thermal conductivity of the Middle Buntsandstein also is reflected in its matrix conductivity values, ranging from $4.2 \pm 0.8 \mathrm{~W} / \mathrm{m} / \mathrm{K}$ (smH, Hardegsen, Gt Ss 1/85 borehole) to $5.5 \pm 0.66 \mathrm{~W} / \mathrm{m} / \mathrm{K}$ (smH, Hardegsen, Gt Ss 2/85 borehole).

The average anisotropy ratio, as a ratio between measured maximum thermal conductivity and minimum conductivity, is small (0.83 - 1.31; mean: $1.02 \pm 0.08)$. No trend of higher values parallel to bedding $\left(\lambda_{\|}\right)$compared to values perpendicular to bedding $\left(\lambda_{\perp}\right)$ is observed.

\subsection{Thermal conductivity calculated from mineral constituents}

Table 2 shows a comparison between measured (A) and calculated (B) saturated bulk formation thermal conductivity and their respective matrix values for a subset of geological formations for which XRD analyses were available. The values are not corrected for in situ temperature.

The difference between measured and calculated bulk values is on average $0.37 \pm 0.23$ $\mathrm{W} / \mathrm{m} / \mathrm{K}$, ranging from $0.1 \mathrm{~W} / \mathrm{m} / \mathrm{K}$ (smD, Detfurth) to $0.7 \mathrm{~W} / \mathrm{m} / \mathrm{K}$ (kOPS, Postera). For matrix values, the average discrepancy is $1.13 \pm 0.62 \mathrm{~W} / \mathrm{m} / \mathrm{K}$, ranging between 0.1 and $1.9 \mathrm{~W} / \mathrm{m} / \mathrm{K}$. The largest differences were observed in the Hardegsen $(\mathrm{smH})$. and Stuttgart $(\mathrm{kmS})$ Formations. Trends of increasing or decreasing discrepancy is related to mineralogy, however, this observation needs a further verification using a larger database.

\subsection{Interval heat flow}

Temperature logs and measured $\lambda$ values were used in the Gt Ss 1/85 borehole and Gt Ss 2/85 borehole (Stralsund area) to indirectly compute $\lambda$ profiles (Fig. 3) using interval (index $i$ ) temperature gradients ( $\nabla T$ ) and a conductive heat-flow value $(q)$ according to equation (4). 


$$
q_{i}=-\lambda_{i} \cdot \nabla T_{i}
$$

This approach follows a concept originally employed by Blackwell and Steele (1989) to indirectly determine a $\lambda$ value for shale imbedded in carbonates.

The temperature logs used in both wells are semi-linear showing only minor breaks correlated to changes in lithology (Fig. 3). No fluid-flow signatures are observed in the log, so that heatconduction conditions are assumed. This is supported by the good correlation between temperature gradient changes and lithological heterogeneity reflected by the gamma-log. Temperature conditions are not affected by heat refraction effects of nearby major salt structures.

The heat flow was computed in four Middle Buntsandstein sandstone intervals of homogeneous temperature gradients (Fig. 4). For each single interval, an average temperature gradient and an average $\lambda$ value was calculated from the laboratory-measured values. The $\lambda$ values were used as temperature-corrected values. The calculated interval heat-flow values vary between $68.4 \mathrm{~mW} / \mathrm{m}^{2}$ and $79.3 \mathrm{~mW} / \mathrm{m}^{2}$ (averaging to $74.2 \pm 4.6 \mathrm{~mW} / \mathrm{m}^{2}$; Gt Ss 1/85 borehole) and between $75.2 \mathrm{~mW} / \mathrm{m}^{2}$ and $81.9 \mathrm{~mW} / \mathrm{m}^{2}$ (averaging to $78.5 \pm 4.8 \mathrm{~mW} / \mathrm{m}^{2}$; Gt Ss 2/85 borehole) (Table 3). The heat-flow interval values are within $8 \%$ and $4 \%$ of the mean value, respectively.

Considering an overburden of the heat-flow interval in this study of about $1400 \mathrm{~m}$ and radiogenic heat-production values for this section as determined by Norden and Förster (2006), a heat-flow component on the order of $1.8 \mathrm{~mW} / \mathrm{m}^{2}$ has to be added to the calculated heat flow for a surface heat flow sensu stricto. This value is within the error range of heatflow determination in this study.

\subsection{Thermal-conductivity profiles}

Using the mean interval heat-flow values and the temperature gradient values versus depth in the two boreholes, in situ thermal conductivity was determined (see equation 4) for the Mesozoic section with a 0.1-m depth resolution. As expected, in the Buntsandstein section the calculated $\lambda$ differs only slightly from the measured values (about $0.24 \pm 0.20 \mathrm{~W} / \mathrm{m} / \mathrm{K}$; Gt Ss 
1/85 borehole and $0.56 \pm 0.51 \mathrm{~W} / \mathrm{m} / \mathrm{K}$; Gt Ss 2/85 borehole) (Fig. 4). Table 4 lists the formation $\lambda$ values, calculated on the basis of a stratigraphic profile (Gt Ss 1/85 borehole), in conjunction with the formation temperature gradients. The lowest $\lambda(1.5 \mathrm{~W} / \mathrm{m} / \mathrm{K})$ is observed in the Toarcian (mostly claystones) and the highest $(3.1 \mathrm{~W} / \mathrm{m} / \mathrm{K})$ in the Hardegsen Formation (mostly sandstones), respectively. In general, however, the formation $\lambda$ values are $<3.0$ $\mathrm{W} / \mathrm{m} / \mathrm{K}$, which for sandy/silty rocks is a reflection of a relatively high porosity.

The impact of lithological heterogeneity on the formation thermal conductivity is reflected in the 1- $\sigma$ standard deviation (Table 4). A high variability is observed in the Upper Jurassic and the Lower Cretaceous. In these formations, claystones of low thermal conductivity alternate with carbonates and sandstones, both of higher thermal conductivity. Resulting from the variability of temperature gradients, the error of a calculated formation thermal conductivity is assumed to be between 0.1 and $1.1 \mathrm{~W} / \mathrm{m} / \mathrm{K}$.

\section{Discussion}

The average measured thermal-conductivity values $(2.1-3.8 \mathrm{~W} / \mathrm{m} / \mathrm{K}$, Table 1$)$ of the Mesozoic sandstones are slightly lower than values published for the Permo-Carboniferous sandstones (2.3 - 4.8 W/m/K; Norden and Förster, 2006). For example, the Permian Elbe and Havel Subgroup, comprised of quartz-cemented, fluvial-lacustrine siltstones and mudstones interbedded with pebbly sandstones has an average thermal conductivity of $4.6 \pm 0.7 \mathrm{~W} / \mathrm{m} / \mathrm{K}$ ( $n=54)$. However, the values for the Permo-Carboniferous are not corrected for in situ temperature conditions. Correction would result in a decrease of about $0.5 \mathrm{~W} / \mathrm{m} / \mathrm{K}$ for saturated laboratory values (after Sass, 1992). In general, the larger bulk values for the Permo-Carboniferous sandstones are related to lower porosity as a result of greater burial depth $(3000-5000 \mathrm{~m})$ compared to the Mesozoic formations, resting at present at 1000 $2000 \mathrm{~m}$. About $85 \%$ of the porosity values $(\mathrm{n}=109)$ of the Permo-Carboniferous rocks are lower than 10 \% (Norden and Förster, 2006). In contrast, the porosity values of the Mesozoic sandstones range between 20 and $35 \%$.

The observed dependence of bulk thermal conductivity on matrix mineralogy is reflected in a strong correlation with calculated matrix thermal conductivity (average values of $3.4-6.5$ $\mathrm{W} / \mathrm{m} / \mathrm{K}$, Table 2). The strongest influence on $\lambda_{\text {matrix }}$ is the volume fraction of quartz (89 - 
$96 \%$, except of the Stuttgart Formation of $48 \%$ ). In general, the aquifer sandstones contain only minor amounts of feldspars and clasts $(<5.4 \%$ and $2.2-8.4 \%$, respectively; Wolfgramm et al., 2008) classifying these rocks as sublitharenites or subarkoses (Pettijohn et al., 1987). An increase of thermal conductivity with increasing quartz content also was described for example by Brigaud et al. (1990) for samples of the Tertiary sedimentary section in the Uinta basin or by Norden and Förster (2006) for the Permian Rotliegend sandstones in the NEGB.

The thermal conductivity measured in the laboratory has been corrected for in situ temperature after Sass (1992). Due to the moderate burial depth of the samples, the corrected values differ only slightly from values under ambient laboratory conditions. Thus, the maximum error introduced by not considering a correction for in situ temperature is about $0.4 \mathrm{~W} / \mathrm{m} / \mathrm{K}$ (average value: $0.17 \pm 0.1 \mathrm{~W} / \mathrm{m} / \mathrm{K}$ ). For $80 \%$ of the corrected values the error would be $<0.2 \mathrm{~W} / \mathrm{m} / \mathrm{K}$.

The interval heat flow determined in the Stralsund area (average $74.2 \pm 4.6 \mathrm{~mW} / \mathrm{m}^{2}$; Gt Ss 1/85 borehole and $78.5 \pm 4.8 \mathrm{~mW} / \mathrm{m}^{2}$; Gt Ss 2/85 borehole) in the Middle Buntsandstein section (Table 3) supports the surface heat-flow values of $68-91 \mathrm{~mW} / \mathrm{m}^{2}$ (Norden et al., 2008). Their values, determined on 13 locations in the NEGB at depths of $1500-5000 \mathrm{~m}$, average to a surface heat flow of $77 \mathrm{~mW} / \mathrm{m}^{2}$. For wells in the particular Stralsund area, the surface heat flow is 76 and $80 \mathrm{~mW} / \mathrm{m}^{2}$ compared to the surface heat flow by Norden et al. (2008) of $74 \mathrm{~mW} / \mathrm{m}^{2}$ (Ba 1/63 borehole), $72 \mathrm{~mW} / \mathrm{m}^{2}$ (Sam 101/62 borehole), and $77 \mathrm{~mW} / \mathrm{m}^{2}$ (Binz 1/73 borehole). The strong similarity between the values indicates that there is no paleoclimate effect on the interval heat flow, determined in the Middle Buntsandstein section (at $1400-1500 \mathrm{~m}$ ).

The calculated thermal-conductivity values based on these heat-flow values show some heterogeneity along the profile, which is a result of variable lithology. The strong negative correlation observed between the gamma-ray and $\lambda$ values in general is indicative of the shale (clay) content. Thus, formations with the highest clay content exhibit the lowest thermal conductivity and vice versa. For example, the Turonian limestones and limy marlstones as well as the Wellenkalk Formation (limestone), reflected as a very homogeneous sections, show a small bandwidth of high temperature gradients and of low gamma response exhibiting low clay content. In the Rhaetian, the interbedding of sandstone, siltstone and claystone also 
is well reflected in both the gamma and the gradient log. The Toarcian (claystones) shows the lowest formation thermal conductivity in the borehole section. In contrast, the Sinemurian and Hettangian sandstones, well distinguishable in the gamma log by its clay content, are not well resolved in the gradient log,

The study performed in three areas of the NEGB reports for the first time laboratorymeasured, in situ thermal conductivity for sandstones of different Mesozoic aquifers. Using some well-log approach, thermal-conductivity values for the entire Mesozoic succession are generated for the Stralsund area in the basin. Together with the thermal-conductivity values for the Permo-Carboniferous formations (Norden and Förster, 2006), a nearly complete geological section with thermal properties is now available to verify the calculated surface heat flow. Further work is planned to enlarge the database for Mesozoic rocks on other locations and further for Cenozoic formations. A larger database of the laboratory thermal conductivity will also allow a validation of the indirectly determined values.

An envisioned systematic basin-wide approach of evaluating the variability of thermal conductivity for key formations would be the basis for a comprehensive evaluation of the geothermal potential of the basin. Up to now, temperature maps are available in the NEGB for the base of the Detfurth Formation (Middle Buntsandstein/Keuper), the Stuttgart (Schilfsandstein) Formation (Keuper), the Jurassic, the Middle Jurassic, and the Lower Cretaceous (from oldest to youngest) (Feldrappe et al., 2008, and references therein). These formations comprise a depth range from about 400 - $2000 \mathrm{~m}$ (with max. temperatures of 120 ${ }^{\circ} \mathrm{C}$ ) in the northeastern part of the basin to about 1600 - $3000 \mathrm{~m}$ (with max. temperatures of $150{ }^{\circ} \mathrm{C}$ ) in the southwestern part, respectively. The mapped temperatures are approximated from an isotherm map at $1500 \mathrm{~m}$ by applying some average geothermal gradient for extrapolation of temperature to different depth. Also, "expert knowledge” was applied to qualitatively correct temperature in the vicinity of major salt structure for heat refraction effects. Thus these maps show a highly resolved temperature pattern, strongly resembling the geological structure, but the pattern itself is not grounded in such a detail on measured borehole data nor on the petrophysical properties of the rocks. Future in-depth studies are needed to elaborate the value of these maps and to advance exploration techniques to revise the mapping. The approach used in this study builds a cornerstone to achieve this goal. 


\section{Acknowledgements}

This study was performed in the framework of the GeoEN (www.geoen.de) project funded by the Federal Ministry of Education and Research (BMBF) in the programme "Spitzenforschung und Innovation in den Neuen Ländern”. We thank the Geothermie Neubrandenburg GmbH (GTN) and the geological survey "Landesamt für Umwelt, Naturschutz und Geologie Mecklenburg Vorpommern” (LUNG) for providing background data from boreholes and core material. Claudia Rach, David Goehring, and Christian Cunow (GFZ) assisted in the laboratory measurements. The work benefited from a review by Niels Balling (Aarhus).

\section{References}

Blackwell, D.D., Steele, J.L., 1989. Heat flow and thermal potential of Kansas. In: Steeples, D.W. (Ed.), Geophysics in Kansas, Kansas Geological Survey Bull. 226, 267-295.

Brigaud, F., Chapman, D.S., Le Douaran, S., 1990. Estimating thermal conductivity in sedimentary basins using lithological data and geophysical well logs. AAPG Bulletin 74, 9, 1459-1477.

Feldrappe, H., Obst, K., Wolfgramm, M., 2008. Mesozoic sandstone aquifers of the North German Basin and their potential for geothermal utilization. Zeitschrift für geologische Wissenschaften 36, 199-222.

Förster, A., 2001. Analysis of borehole temperature data in the Northeast German Basin: Continuous logs versus bottom-hole temperatures. Petroleum Geoscience 7, 3, 241-254.

Förster, A., Norden, B., Zinck-Jørgensen, K., Frykman, P., Kulenkampff, J., Spangenberg, E., Erzinger, J., Zimmer, M., Kopp, J., Borm, G., Juhlin, C., Cosma, C.-G., Hurter, S., 2006. Baseline characterization of the $\mathrm{CO}_{2} \mathrm{SINK}$ geological storage site at Ketzin, Germany: Environmental Geosciences 13, 3, 145-161.

Schön, J., 1996. Physical properties of rocks, fundamentals and principles of petrophysics, in: Handb. Geophy. Explor., Sect. 1, Pergamon, Oxford, UK, 583 pp.

LUNG (Geologisches Landesamt Mecklenburg - Vorpommern), 1997. Geologische Karte von Mecklenburg - Vorpommern: Übersichtskarte 1:500.000 - Strukturen im Untergrund nach oberflächengeophysikalischen Ergebnissen (Zechsteinsalzstrukturen), 1. Auflage. 
Hoth, K., Rusbueldt, J., Zagora, K., Beer, H. \& Hartmann, O., 1993. Die tiefen Bohrungen im Zentralabschnitt der Mitteleuropäischen Senke - Dokumentation für den Zeitabschnitt 1962-1990. Gesellschaft für Geowissenschaften e.V., Berlin, Germany.

Horai, K., 1971. Thermal Conductivity of Rock-Forming Minerals, Journal of Geophysical Research 76, 5, 1278 - 1308.

LIAG, 2009. Geophysics Information System. http://www.liag-hannover.de/en/research-ofmethods-sections/geothermics-information-systems/projects/fis-gp-geophysicsinformation-system.html.

Norden, B., Förster, A., 2006. Thermal conductivity and radiogenic heat production of sedimentary and magmatic rocks in the Northeast German Basin, AAPG Bulletin 90, 6, 939-962.

Norden, B., Förster, A., Balling, N., 2008. Heat flow and lithospheric thermal regime in the Northeast German Basin. Tectonophysics 460, 215-229.

Pettijohn, F.J., Potter, P.E., Siever, R., 1987. Sand and sandstone. Springer-Verlag, Berlin, 533 pp.

Popov, Y.A., Pribnow, D.F.C., Sass, J.H., Williams, C.F., Burkhardt, H., 1999. Characterization of rock thermal conductivity by high-resolution optical scanning. Geothermics 28, 253-276.

Sass, J.H., Lachenbruch, A.H., Moses, Jr., T.H., 1992. Heat flow from a scientific research well at Cajon Pass, California. J. Geophysical Research, 97, 5017-5030.

Sass, J.H., Lachenbruch, A.H., Munroe, R.J., 1971. Thermal conductivity of rocks from measurements on fragments and its application to heat-flow determinations. Journal of Geophysical Research 76, 3391-3401.

Sass, J.H., Stone, C., Munroe, R.J., 1984. Thermal conductivity determinations on solid rock - a comparison between steady-state divided bar apparatus and a commercial transient line-source device. Journal of Volcanology and Geothermal Research, 20, 145-153.

Wolfgramm, M., Rauppach, K., Seibt, P., 2008. Reservoir-geological characterization of Mesozoic sandstones in the North German Basin by petrophysical and petrographical data. Zeitschrift für geologische Wissenschaften 36, 249-265. 


\section{Table captions}

Table 1 . Thermal conductivity of water saturated samples corrected for in situ temperature (LUNG, 1997).

Table 2. Comparison of (A) thermal conductivity measured saturated ( $\lambda$ bulk) and respective matrix thermal conductivity ( $\lambda$ matrix) (uncorrected values) and (B) bulk thermal conductivity for saturated samples based on in-situ matrix thermal conductivity, calculated from mineral constituents and porosity. Pore fill is water.

Table 3. Heat flow calculated for the Stralsund area.

Table 4. Average bulk thermal conductivity calculated for Mesozoic formations in conjunction with formation temperature gradients (Gt Ss 1/85 borehole). 


\section{Figure captions}

Figure 1. Study area in the NEGB. The thickness of the Permian Zechstein formation is shaded grey (CI: $250 \mathrm{~m}$ ). Grey solid circles show boreholes of this study selected from a pool of geothermal exploration wells (open circles) available in the area. Bold lines show major faults of Mesozoic age; broken line is the 500-m-depth isoline of top Zechstein; open triangles denotes the location of cities.

Figure 2. Generalized stratigraphic column of the Mesozoic with major geothermal sandstone aquifers (dotted pattern; modified after Feldrappe et al., 2008). Black-dotted intervals are the studied aquifers.

Figure 3. Thermal conductivity $(\lambda)$, temperature $(T)$, temperature gradient $\left(T_{\text {grad }}\right)$ and gammaray (GR) profiles of the Mesozoic section (Gt Ss 1/85 borehole).

Figure 4. Thermal-conductivity profiles calculated for the Gt Ss 1/85 borehole and Gt Ss 2/85 borehole in the Stralsund area. Dots show thermal conductivity measured on saturated samples, open circles show average matrix thermal conductivity calculated from dry and saturated measurements and porosity. Grey lines attached to the lithoprofile show the intervals for which mean temperature gradients were calculated; black bold doted line indicates the average temperature gradient, thin dotted grey line show the gamma-ray. 


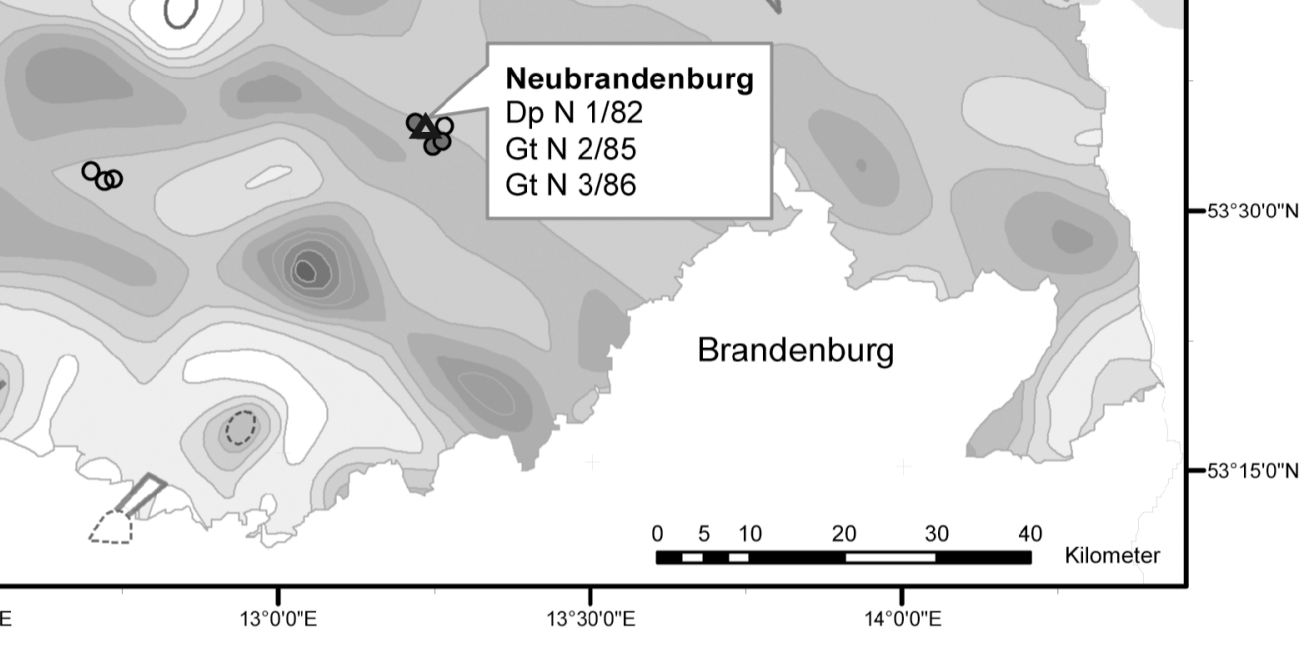

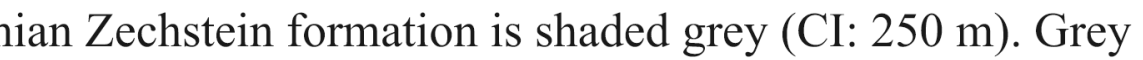

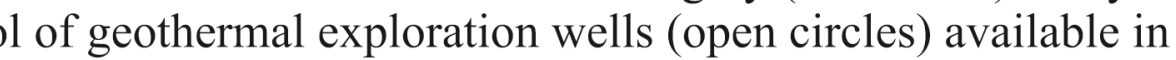

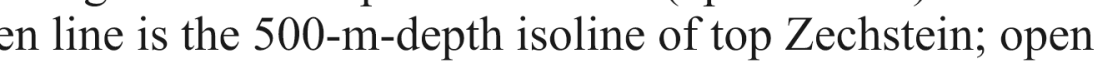




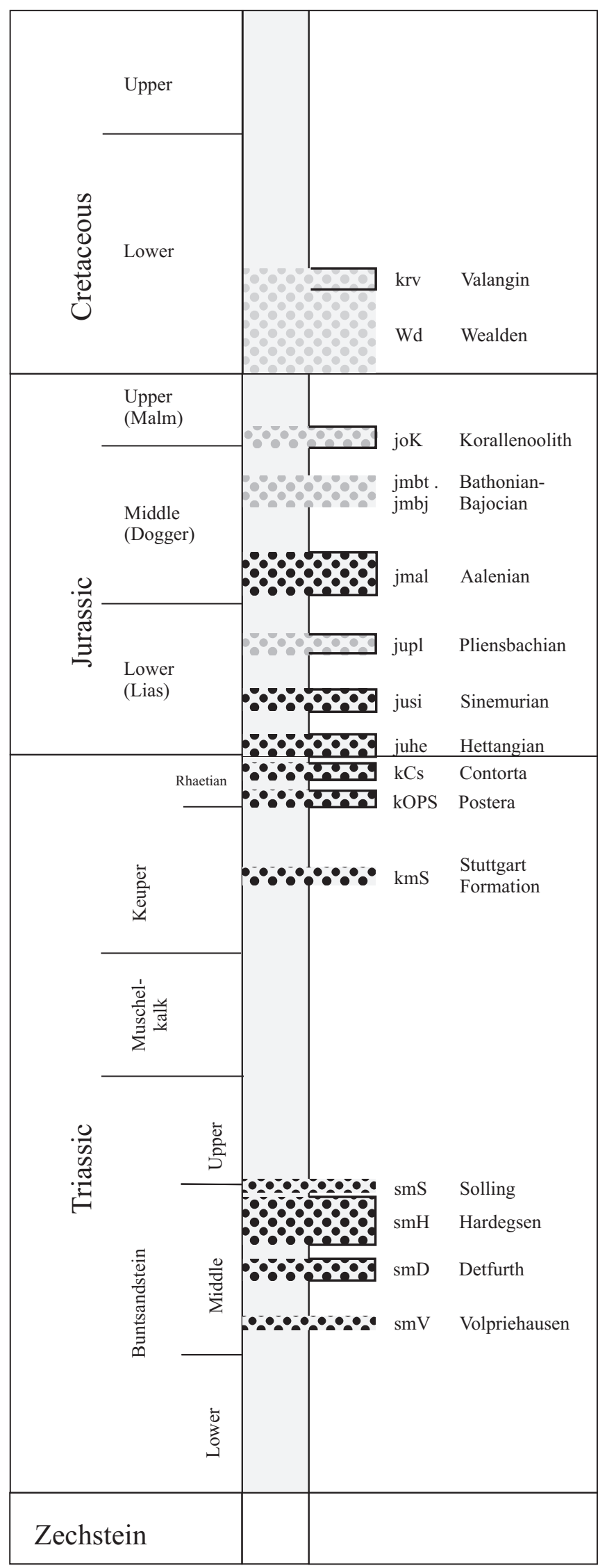

Figure 2. Generalized stratigraphic column of the Mesozoic with major geothermal sandstone aquifers (dotted pattern; modified after Wolfgramm et al., 2004). Black-dotted intervals are the studied aquifers. 


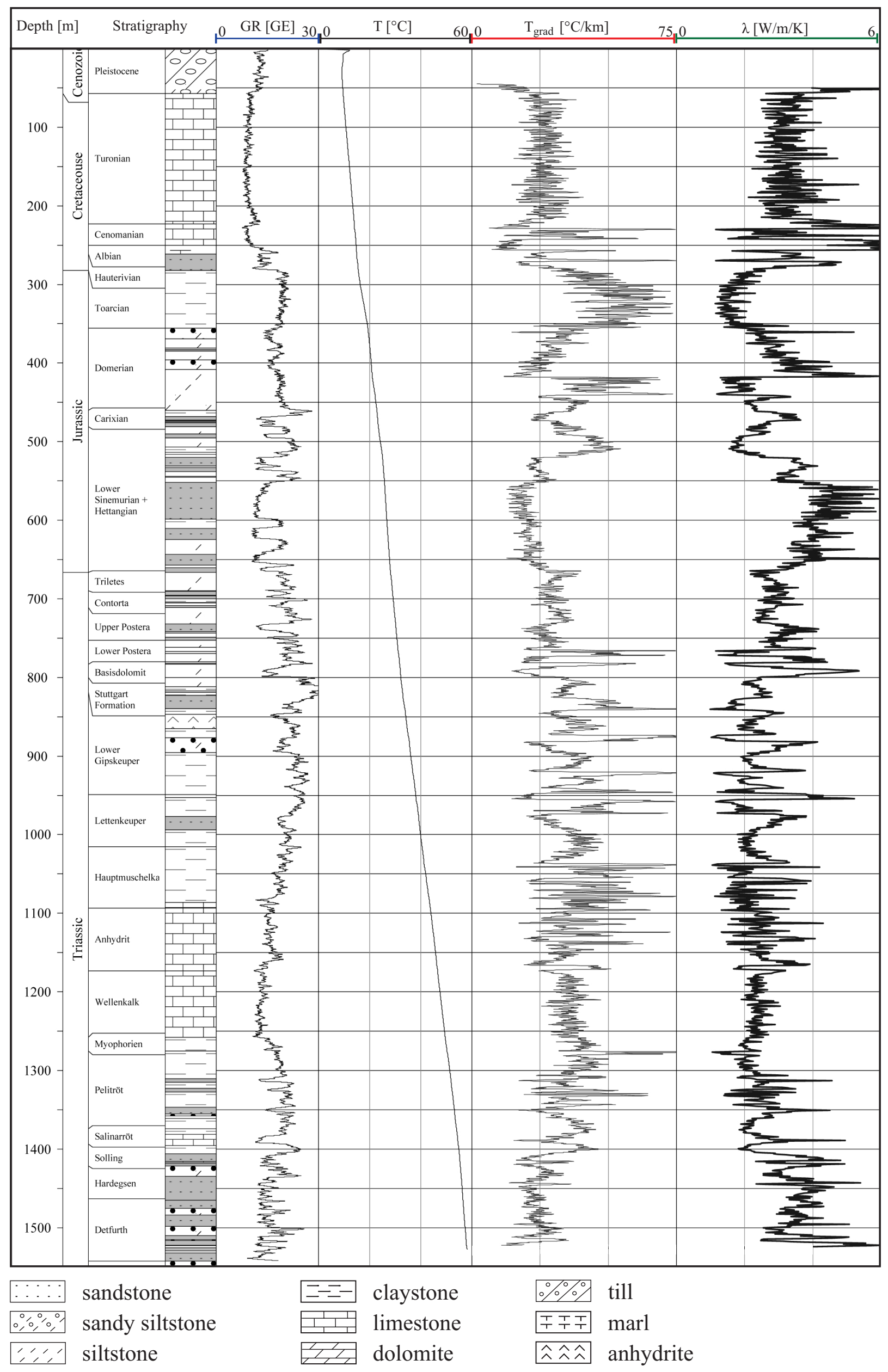

Figure 3. Thermal-conductivity $(\lambda)$, temperature $(T)$, temperature gradient $\left(\mathrm{T}_{\text {grad }}\right)$ and gammaray (GR) profiles of the Mesozoic section (Gt Ss 1/85 borehole). 


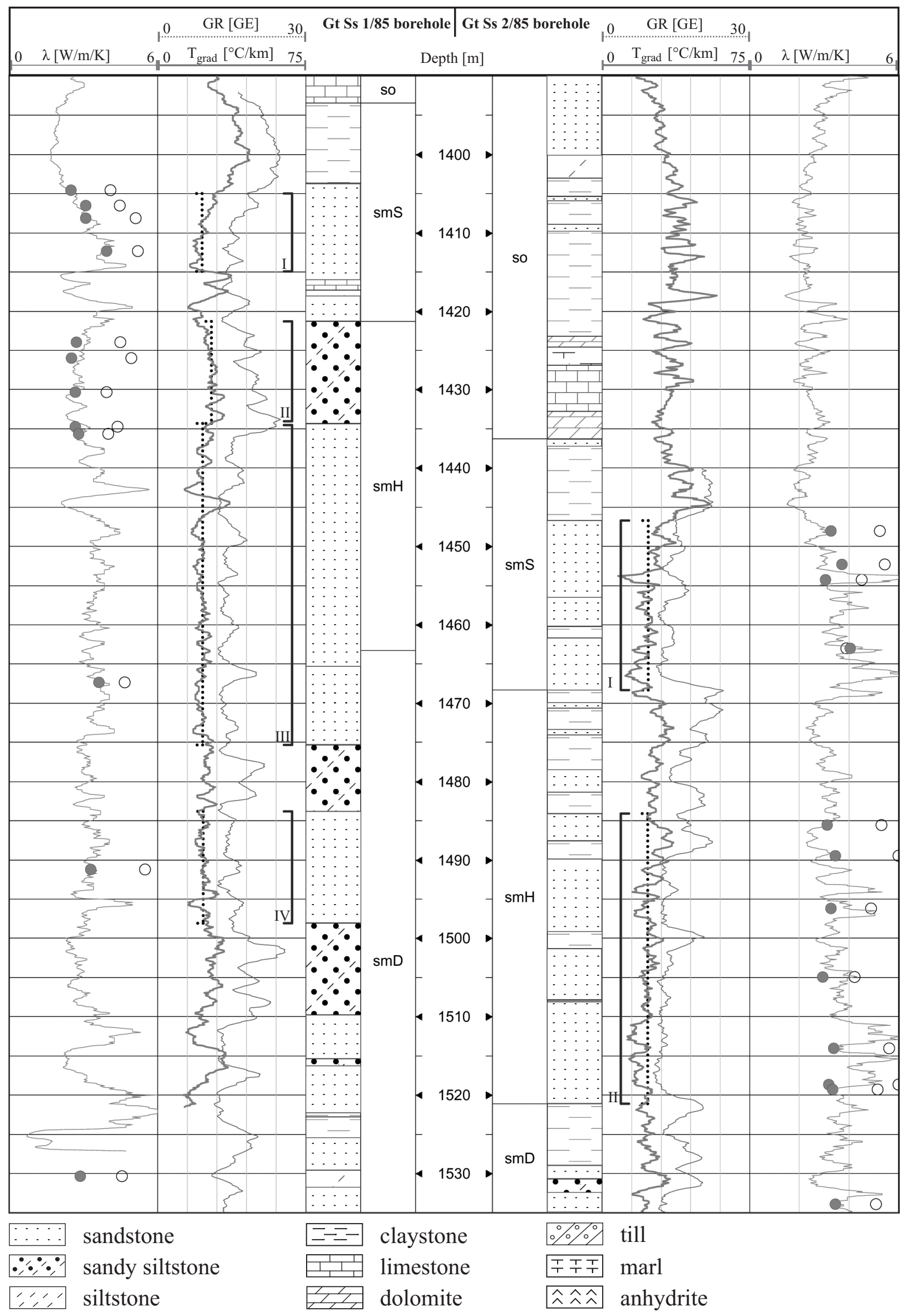

Figure 4. Thermal-conductivity profiles calculated for the Gt Ss 1/85 borehole and Gt Ss 2/85 borehole in the Stralsund area. Dots show thermal conductivity measured on saturated samples, open circles show average matrix thermal conductivity calculated from dry and saturated measurements and porosity. Grey lines attached to the lithoprofile show the intervals for which mean temperature gradients were calculated; black bold doted line indicates the average temperature gradient, thin dotted grey line show the gamma-ray. 
Table 1. Thermal conductivity of saturated samples corrected for in situ temperature.

\begin{tabular}{|c|c|c|c|c|c|c|}
\hline \multirow{2}{*}{ Stratigraphic Unit } & \multirow{2}{*}{ Borehole } & \multirow{2}{*}{$\begin{array}{l}\text { Depth } \\
\text { [m] }\end{array}$} & \multicolumn{2}{|r|}{$\lambda_{\perp_{\text {satM }}}$} & \multirow{2}{*}{ 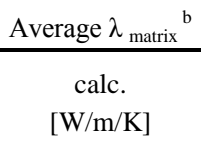 } & \multirow{2}{*}{$\begin{array}{c}\text { Effective } \\
\text { Porosity } \\
\text { [\%] }\end{array}$} \\
\hline & & & meas. & $\begin{array}{l}\text { corrected }^{\mathrm{a}} \\
{[\mathrm{W} / \mathrm{m} / \mathrm{K}]}\end{array}$ & & \\
\hline (jupl) & Dp N 1/82 & 991.2 & 3.6 & 3.5 & $5,5 \pm 0,3$ & 21.4 \\
\hline \multirow[t]{2}{*}{ (jupl) } & Dp N 1/82 & 1017.0 & 3.1 & 3.0 & $6,1 \pm 1,1$ & 26.1 \\
\hline & & & 3.4 & 3.3 & 5.8 & 23.8 \\
\hline (jusi) & Dp N 1/82 & 1134.6 & 3.2 & 3.1 & $5,6 \pm 1$ & 28.4 \\
\hline \multirow[t]{2}{*}{ (jusi) } & Dp N 1/82 & 1136.0 & 3.2 & 3.0 & $5,6 \pm 0,8$ & 28.2 \\
\hline & & & 3.2 & 3.1 & 5.6 & 28.3 \\
\hline (juhe) & Gt N 3/86 & 1120.5 & 3.3 & 3.2 & $5,2 \pm 0$ & 22.4 \\
\hline (juhe) & Gt N 3/86 & 1122.6 & 3.6 & 3.5 & $6,7 \pm 0,6$ & 24.8 \\
\hline (juhe) & Gt N 3/86 & 1124.3 & 3.5 & 3.3 & $5,1 \pm 0,3$ & 21.1 \\
\hline (juhe) & Gt N 3/86 & 1125.7 & 4.0 & 3.8 & $4,5 \pm 1,7$ & 16.5 \\
\hline (juhe) & Gt N 3/86 & 1144.2 & 3.0 & 2.9 & $7,6 \pm 1,3$ & 32.4 \\
\hline (juhe) & Gt N 3/86 & 1145.9 & 3.4 & 3.3 & $6,2 \pm 0,1$ & 26.9 \\
\hline (juhe) & Gt N 3/86 & 1150.7 & 3.2 & 3.1 & $6,1 \pm 0,1$ & 27.4 \\
\hline (juhe) & Gt N 3/86 & 1153.1 & 3.3 & 3.2 & $7,4 \pm 0,2$ & 31.5 \\
\hline (juhe) & Gt N 3/86 & 1154.0 & 3.2 & 3.1 & $5,5 \pm 0,2$ & 25.7 \\
\hline (juhe) & Gt N 3/86 & 1157.5 & 3.3 & 3.1 & $5,5 \pm 0,9$ & 26.7 \\
\hline \multirow[t]{2}{*}{ (juhe) } & Gt N 3/86 & 1159.3 & 3.3 & 3.2 & $6,9 \pm 0,3$ & 29.6 \\
\hline & & & 3.4 & 3.2 & 6.1 & 25.9 \\
\hline$(\mathrm{kCs})$ & Gt N 2/85 & 1222.1 & 3.4 & 3.2 & $5,2 \pm 0,3$ & 20.0 \\
\hline (kCs) & Gt N 2/85 & 1225.3 & 3.2 & 3.1 & $6,3 \pm 1,1$ & 25.3 \\
\hline \multirow[t]{2}{*}{ (kCs) } & Gt N 2/85 & 1229.4 & 3.8 & 3.6 & $5,5 \pm 0,1$ & 18.7 \\
\hline & & & 3.5 & 3.3 & 6.2 & 21.3 \\
\hline \multirow[t]{2}{*}{ (kCs) } & Dp N 1/82 & 1252.0 & 3.5 & 3.3 & $4,7 \pm 1,3$ & 21.9 \\
\hline & & & 3.5 & 3.3 & 5.9 & 21.9 \\
\hline$(\mathrm{kCs})$ & Gt S 5/87 & 2063.2 & 4.0 & 3.7 & $6,8 \pm 0,5$ & 25.5 \\
\hline (kCs) & Gt S 5/87 & 2072.1 & 4.2 & 3.8 & $6,7 \pm 0,1$ & 22.8 \\
\hline (kCs) & Gt S 5/87 & 2072.7 & 4.1 & 3.7 & $7,4 \pm 1,4$ & 23.7 \\
\hline (kCs) & Gt S 5/87 & 2072.9 & 4.5 & 4.0 & $6,1 \pm 0,4$ & 20.0 \\
\hline$(\mathrm{kCs})$ & Gt S 5/87 & 2109.5 & 4.4 & 4.0 & $6,5 \pm 0,3$ & 20.1 \\
\hline (kCs) & Gt S 5/87 & 2110.5 & 4.2 & 3.8 & $6,1 \pm 0,1$ & 20.5 \\
\hline (kCs) & Gt S 5/87 & 2112.4 & 3.7 & 3.4 & $6,2 \pm 0,9$ & 22.3 \\
\hline$(\mathrm{kCs})$ & Gt S 5/87 & 2113.1 & 4.0 & 3.6 & $5,5 \pm 0$ & 18.8 \\
\hline (kCs) & Gt S 5/87 & 2114.2 & 4.2 & 3.8 & $7,2 \pm 0,9$ & 23.0 \\
\hline \multirow[t]{2}{*}{$(\mathrm{kCs})$} & Gt S 5/87 & 2115.2 & 4.1 & 3.7 & $8 \pm 2,8$ & 22.6 \\
\hline & & & 4.1 & 3.8 & 6.6 & 21.9 \\
\hline (kOPS) & Gt S 5/87 & 2136.5 & 4.5 & 4.1 & $7,7 \pm 1,2$ & 22.0 \\
\hline \multirow[t]{2}{*}{ (kOPS) } & Gt S 5/87 & 2136.9 & 4.1 & 3.7 & $7,1 \pm 1,3$ & 22.1 \\
\hline & & & 4.3 & 3.9 & 7.4 & 22.0 \\
\hline (kOPS) & Dp N 1/82 & 1274.6 & 3.8 & 3.6 & $5,2 \pm 0,3$ & 22.4 \\
\hline (kOPS) & Dp N 1/82 & 1275.0 & 3.7 & 3.5 & $6,3 \pm 1,1$ & 26.3 \\
\hline \multirow[t]{2}{*}{ (kOPS) } & Dp N 1/82 & 1281.8 & 3.3 & 3.2 & $5,5 \pm 0,1$ & 25.2 \\
\hline & & & 3.6 & 3.4 & 5.7 & 24.7 \\
\hline (kOPS) & Gt N 2/85 & 1255.5 & 3.6 & 3.5 & $7,8 \pm 0,1$ & 30.5 \\
\hline \multirow[t]{2}{*}{ (kOPS) } & Gt N 2/85 & 1261.0 & 3.1 & 3.0 & $7,1 \pm 1,2$ & 30.0 \\
\hline & & & 3.4 & 3.2 & 7.4 & 30.3 \\
\hline$(\mathrm{kmS})$ & Gt N 2/85 & 1517.5 & 1.9 & 1.9 & $2,4 \pm 0,2$ & 11.0 \\
\hline (kmS) & Gt N 2/85 & 1525.4 & 2.1 & 2.1 & $2,7 \pm 0,2$ & 13.7 \\
\hline (kmS) & Gt N 2/85 & 1528.0 & 2.0 & 2.0 & $3,2 \pm 0,9$ & 17.0 \\
\hline (kmS) & Gt N 2/85 & 1537.7 & 2.1 & 2.1 & $4,3 \pm 0,8$ & 26.3 \\
\hline \multirow[t]{2}{*}{$(\mathrm{kmS})$} & Gt N 2/85 & 1541.7 & 2.2 & 2.2 & $4,2 \pm 0,2$ & 25.8 \\
\hline & & & 2.1 & 2.1 & 3.4 & 18.8 \\
\hline (smS) & Gt Ss $1 / 85$ & 1404.6 & 2.6 & 2.5 & $4,1 \pm 0,9$ & 19.0 \\
\hline (smS) & Gt Ss 1/85 & 1406.6 & 3.2 & 3.1 & $4,5 \pm 0,1$ & 18.8 \\
\hline (smS) & Gt Ss 1/85 & 1408.2 & 3.2 & 3.1 & $5,3 \pm 0$ & 23.2 \\
\hline$(\mathrm{smS})$ & Gt Ss 1/85 & 1412.3 & 4.2 & 3.9 & $5,3 \pm 1,2$ & 18.5 \\
\hline & & & 3.3 & 3.2 & 4.8 & 19.9 \\
\hline$(\mathrm{smS})$ & Gt Ss 2/85 & 1448.1 & 3.4 & 3.3 & $5,3 \pm 0,4$ & 19.8 \\
\hline
\end{tabular}




\begin{tabular}{|c|c|c|c|c|c|c|}
\hline$(\mathrm{smS})$ & Gt Ss 2/85 & 1452.3 & 3.9 & 3.7 & $5,6 \pm 0,9$ & 21.5 \\
\hline (smS) & Gt Ss 2/85 & 1454.3 & 3.2 & 3.0 & $4,5 \pm 0,4$ & 16.9 \\
\hline \multirow[t]{2}{*}{$(\mathrm{smS})$} & Gt Ss 2/85 & 1463.0 & 4.3 & 4.0 & $3,9 \pm 0,9$ & 6.0 \\
\hline & & & 3.7 & 3.5 & 4.8 & 16.1 \\
\hline$(\mathrm{smH})$ & Gt Ss $1 / 85$ & 1424.0 & 2.8 & 2.7 & $4,7 \pm 0,2$ & 24.0 \\
\hline$(\mathrm{smH})$ & Gt Ss $1 / 85$ & 1426.0 & 2.6 & 2.5 & $2,8 \pm 0,1$ & 22.0 \\
\hline$(\mathrm{smH})$ & Gt Ss $1 / 85$ & 1430.4 & 2.8 & 2.7 & $4,4 \pm 0,6$ & 25.0 \\
\hline$(\mathrm{smH})$ & Gt Ss $1 / 85$ & 1434.7 & 2.7 & 2.7 & $4,5 \pm 0,5$ & 22.0 \\
\hline \multirow[t]{2}{*}{$(\mathrm{smH})$} & Gt Ss $1 / 85$ & 1435.6 & 2.9 & 2.8 & $4,4 \pm 0,7$ & 24.0 \\
\hline & & & 2.8 & 2.7 & 4.2 & 23.4 \\
\hline$(\mathrm{smH})$ & Gt Ss 2/85 & 1485.5 & 3.3 & 3.1 & $5,5 \pm 0,2$ & 23.5 \\
\hline$(\mathrm{smH})$ & Gt Ss 2/85 & 1489.5 & 3.6 & 3.5 & $6,2 \pm 0$ & 24.1 \\
\hline$(\mathrm{smH})$ & Gt Ss 2/85 & 1496.2 & 3.4 & 3.3 & $5 \pm 0,3$ & 21.0 \\
\hline$(\mathrm{smH})$ & Gt Ss 2/85 & 1504.9 & 3.1 & 2.9 & $4,6 \pm 0,8$ & 23.5 \\
\hline$(\mathrm{smH})$ & Gt Ss 2/85 & 1514.1 & 3.6 & 3.4 & $5,7 \pm 0,2$ & 21.7 \\
\hline$(\mathrm{smH})$ & Gt Ss 2/85 & 1518.7 & 3.3 & 3.2 & $6,5 \pm 0,7$ & 26.4 \\
\hline \multirow[t]{2}{*}{$(\mathrm{smH})$} & Gt Ss 2/85 & 1519.3 & 3.5 & 3.3 & $5,3 \pm 0,2$ & 21.4 \\
\hline & & & 3.4 & 3.2 & 5.5 & 23.1 \\
\hline (smD) & Gt Ss $1 / 85$ & 1467.4 & 3.8 & 3.6 & $4,8 \pm 1,2$ & 19.1 \\
\hline (smD) & Gt Ss $1 / 85$ & 1491.2 & 3.5 & 3.3 & $4,9 \pm 1$ & 22.5 \\
\hline (smD) & Gt Ss $1 / 85$ & 1530.3 & 3.0 & 2.9 & $4,6 \pm 0,6$ & 19.1 \\
\hline \multirow[t]{2}{*}{ (smD) } & Gt Ss $1 / 85$ & 1540.9 & 3.1 & 3.0 & $4,5 \pm 1,3$ & 18.0 \\
\hline & & & 3.3 & 3.2 & 4.7 & 19.7 \\
\hline (smD) & Gt Ss 2/85 & 1533.9 & 3.7 & 3.5 & $5,1 \pm 0,2$ & 17.1 \\
\hline (smD) & Gt Ss 2/85 & 1540.6 & 3.3 & 3.1 & $5 \pm 0$ & 21.7 \\
\hline (smD) & Gt Ss 2/85 & 1545.2 & 3.0 & 2.9 & $4,2 \pm 0,4$ & 21.0 \\
\hline (smD) & Gt Ss 2/85 & 1547.6 & 3.2 & 3.0 & $5 \pm 0,2$ & 23.0 \\
\hline (smD) & Gt Ss 2/85 & 1560.1 & 3.5 & 3.3 & $5,5 \pm 0,1$ & 21.6 \\
\hline (smD) & Gt Ss 2/85 & 1562.2 & 3.3 & 3.1 & $4,8 \pm 0,2$ & 20.4 \\
\hline (smD) & Gt Ss 2/85 & 1568.9 & 3.8 & 3.6 & $6,6 \pm 0,6$ & 23.7 \\
\hline (smD) & Gt Ss 2/85 & 1577.6 & 3.6 & 3.4 & $6,4 \pm 0$ & 25.7 \\
\hline \multirow[t]{2}{*}{ (smD) } & Gt Ss 2/85 & 1602.1 & 3.5 & 3.4 & $3,8 \pm 0,3$ & 9.6 \\
\hline & & & 3.4 & 3.3 & 5.1 & 20.4 \\
\hline
\end{tabular}

${ }^{\mathrm{a}}$ Temperature corrected after Sass et al. (1992); ${ }^{\mathrm{b}}$ Based on corrected values. 
Table 2: Comparison of (A) thermal conductivity measured saturated ( $\lambda$ bulk) and respective matrix thermal conductivity $(\lambda$ matrix) (uncorrected values) and (B) bulk thermal conductivity for saturated samples based on in-situ matrix thermal conductivity, calculated from mineral constituents and porosity. Pore fill is water.

\begin{tabular}{|c|c|c|c|c|c|c|c|c|c|c|c|}
\hline \multirow{4}{*}{ Location } & \multirow{4}{*}{$\begin{array}{l}\text { Stratigraphic } \\
\text { Unit }\end{array}$} & \multirow{4}{*}{$\begin{array}{c}\text { No. } \\
\text { Sample }\end{array}$} & \multicolumn{2}{|c|}{ (A) } & \multirow{4}{*}{$\begin{array}{c}\text { No. } \\
\text { Sample }\end{array}$} & \multicolumn{6}{|c|}{ (B) } \\
\hline & & & $\lambda_{\text {bulk }}$ & $\lambda_{\text {matrix }}$ & & \multicolumn{4}{|c|}{ Mineral Composition ${ }^{\mathrm{a}}$} & \multirow{2}{*}{$\lambda_{\text {bulk }}$} & \multirow{2}{*}{$\frac{\lambda_{\text {matrix }}}{\text { mean }}$} \\
\hline & & & mean & mean & & Quartz & $\begin{array}{l}\text { Alkali } \\
\text { feldspar }\end{array}$ & $\begin{array}{l}\text { Plagio- } \\
\text { clase }\end{array}$ & Others & & \\
\hline & & & \multicolumn{2}{|c|}{$[\mathrm{W} / \mathrm{m} / \mathrm{K}]$} & & [\%] & [\%] & [\%] & [\%] & {$[\mathrm{W} /$} & $\mathrm{a} / \mathrm{K}]$ \\
\hline Neubrandenburg & (juhe) & 11 & 3.4 & 6.1 & 6 & 85 & 3 & 3 & 10 & 3.3 & 6.8 \\
\hline Neubrandenburg & $(\mathrm{kCs})$ & 1 & 3.5 & 5.7 & 3 & 64 & 5 & 7 & 24 & 3.0 & 4.5 \\
\hline Neubrandenburg & (kOPS) & 3 & 3.5 & 6.5 & 2 & 82 & 2 & 2 & 14 & 3.2 & 6.2 \\
\hline Neubrandenburg & $(\mathrm{kmS})$ & 5 & 2.1 & 3.4 & 8 & 48 & 5 & 26 & 21 & 2.7 & 4.2 \\
\hline Stralsund & $(\mathrm{smS})$ & 4 & 3.3 & 4.8 & 6 & 78 & 9 & 4 & 10 & 3.6 & 6.1 \\
\hline Stralsund & $(\mathrm{smH})$ & 5 & 2.8 & 4.3 & 7 & 80 & 9 & 3 & 8 & 3.5 & 6.2 \\
\hline Stralsund & (smD) & 4 & 3.3 & 4.9 & 4 & 83 & 6 & 2 & 9 & 3.5 & 6.5 \\
\hline
\end{tabular}

${ }^{a}$ Thermal conductivity of minerals: quartz: $7.7 \mathrm{~W} / \mathrm{m} / \mathrm{K}^{*}$, alkali feldspar: $2.3 \mathrm{~W} / \mathrm{m} / \mathrm{K}^{*}$, plagioclase: $2.31 \mathrm{~W} / \mathrm{m} / \mathrm{K}^{* *}$, kaolinite: 2.6 $\mathrm{W} / \mathrm{m} / \mathrm{K}^{* *}$, calcite: $3.57 \mathrm{~W} / \mathrm{m} / \mathrm{K}^{* *}$, dolomite: $4.7 \mathrm{~W} / \mathrm{m} / \mathrm{K}^{* *}$ and halite: $5.6 \mathrm{~W} / \mathrm{m} / \mathrm{K}^{* *}$.

${ }^{*}$ (Horai, 1971), ${ }^{* *}$ (Schön, 1996). 
Table 3. Heat-flow calculated for the Stralsund area.

\begin{tabular}{|c|c|c|c|c|c|c|}
\hline \multirow[t]{2}{*}{ Interval } & Depth interval & \multirow[t]{2}{*}{ Stratigraphic unit } & \multirow[t]{2}{*}{ No. $\lambda$ values } & \multirow{2}{*}{$\begin{array}{c}\begin{array}{c}\text { Equilibrium } \\
\text { temperature } \\
\text { gradient }\end{array} \\
{\left[{ }^{\circ} \mathrm{C} / \mathrm{km}\right]}\end{array}$} & \multirow{2}{*}{ 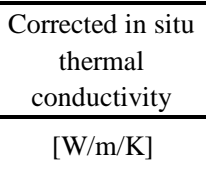 } & \multirow{2}{*}{$\begin{array}{c}\begin{array}{c}\text { Calculated heat } \\
\text { flow }\end{array} \\
{\left[\mathrm{mW} / \mathrm{m}^{2}\right]}\end{array}$} \\
\hline & {$[\mathrm{m}]$} & & & & & \\
\hline \multicolumn{7}{|c|}{ Gt Ss $1 / 85$ borehole } \\
\hline I & 1405.90 - 1415.95 & $(\mathrm{smS})$ & 3 & $23.5 \pm 3.4$ & $3.37 \pm 0.4$ & 79.3 \\
\hline II & 1421.30 - 1434.30 & $(\mathrm{smH})$ & 3 & $27.3 \pm 3.1$ & $2.69 \pm 0.03$ & 73.3 \\
\hline III & 1434.00 - 1475.30 & (smH, smD) & 3 & $22.7 \pm 3.5$ & $3.02 \pm 0.42$ & 68.4 \\
\hline \multirow[t]{2}{*}{ IV } & 1483.80 - 1498.10 & $(\mathrm{smD})$ & 1 & $23.1 \pm 2.9$ & $3.29 \pm 0$ & 75.9 \\
\hline & & & & & average: & $74.2 \pm 4.6$ \\
\hline \multicolumn{7}{|c|}{ Gt Ss 2/85 borehole } \\
\hline I & $1446.70-1456.40$ & $(\mathrm{smS})$ & 4 & $23.3 \pm 5.5$ & $3.52 \pm 0.45$ & 81.9 \\
\hline \multirow[t]{2}{*}{ II } & 1484.85 - 1521.10 & $(\mathrm{smH})$ & 7 & $23.2 \pm 5$ & $3.24 \pm 0.18$ & 75.2 \\
\hline & & & & & average: & $78.5 \pm 4.8$ \\
\hline
\end{tabular}


Table 4. Average bulk thermal conductivity calculated for Cenozoic and Mesozoic formations in conjunction with formation temperature gradients (Gt Ss 1/85 borehole).

\begin{tabular}{|c|c|c|c|c|c|}
\hline Depth & & & Stratigraphy & $\begin{array}{c}\text { Temperature } \\
\text { gradient }\end{array}$ & $\begin{array}{l}\text { Calculated average } \\
\text { bulk thermal } \\
\text { conductivity }^{\mathrm{a}}\end{array}$ \\
\hline$[\mathrm{m}]$ & & & & {$\left[{ }^{\circ} \mathrm{C}\right]$} & {$[\mathrm{W} / \mathrm{m} / \mathrm{K}]$} \\
\hline 57 & 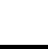 & (qр) & Pleistocene & - & - \\
\hline 223 & $\cong$ & (krt) & Turonian & $26.3 \pm 4.7$ & $2.8 \pm 0.4$ \\
\hline 250 & ¿्ّ & (krc) & Cenomanian & $26.6 \pm 16.1$ & $2.8 \pm 1.1$ \\
\hline 261 & 莺 & $(\mathrm{krl})$ & Albian & $24.7 \pm 12.6$ & $3 \pm 1$ \\
\hline 282 & & (krh) & Hauterivian & $28.7 \pm 12.4$ & $2.6 \pm 0.8$ \\
\hline 356 & & (jutc) & Toarcian & $50.8 \pm 10.6$ & $1.5 \pm 0.3$ \\
\hline 460 & 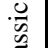 & (juplo) & Domerian (Upper Pliensbachian) & $33.8 \pm 11.4$ & $2.2 \pm 0.6$ \\
\hline 481 & 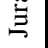 & (juplu) & Carixian (Lower Pliensbachian) & $28.9 \pm 4.2$ & $2.6 \pm 0.3$ \\
\hline 666 & & (jusiu+juhe) & Lower Sinemurian + Hettangian & $25.7 \pm 9.3$ & $2.9 \pm 0.8$ \\
\hline 690 & & (kTs) & Upper Keuper / Triletes & $30.4 \pm 3.6$ & $2.4 \pm 0.3$ \\
\hline 711 & & $(\mathrm{kCs})$ & Upper Keuper / Contorta & $28.3 \pm 3.1$ & $2.6 \pm 0.3$ \\
\hline 753 & & (kOPS) & Upper Keuper / Upper Postera & $29.2 \pm 4.4$ & $2.5 \pm 0.3$ \\
\hline 783 & & (kmSM2-3) & Upper Keuper / Lower Postera & $33.7 \pm 14.2$ & $2.2 \pm 0.7$ \\
\hline 800 & & (kmSM1) & Upper Keuper / Basisdolomit & $26 \pm 9.6$ & $2.9 \pm 0.8$ \\
\hline 819 & & $(\mathrm{kmS})$ & Middle Keuper / Stuttgart Formation & $36.1 \pm 3.3$ & $2.1 \pm 0.2$ \\
\hline 949 & & $(\mathrm{kmGu})$ & Middle Keuper / Lower Gipskeuper & $40 \pm 12.6$ & $1.9 \pm 0.4$ \\
\hline 1015 & & $(\mathrm{ku})$ & Lower Keuper / Lettenkeuper & $36.9 \pm 11.6$ & $2 \pm 0.5$ \\
\hline 1093 &.$\simeq$ & $(\mathrm{mm})$ & Upper Muschelkalk / Hauptmuschelkalk & $41.3 \pm 12.4$ & $1.8 \pm 0.4$ \\
\hline 1173 & . & $(\mathrm{mmAN})$ & Middle Muschelkalk / Anhydrit & $35.6 \pm 9.8$ & $2.1 \pm 0.5$ \\
\hline 1258 & & (mu) & Lower Muschelkalk / Wellenkalk & $35.2 \pm 3.6$ & $2.1 \pm 0.2$ \\
\hline 1275 & & (soMY) & Upper Buntsandstein / Myophorien & $40.4 \pm 3$ & $1.8 \pm 0.1$ \\
\hline 1374 & & (soPR) & Upper Buntsandstein / Pelitröt & $37.4 \pm 9.7$ & $2 \pm 0.4$ \\
\hline 1393 & & (soSR) & Upper Buntsandstein / Salinarröt & $34.1 \pm 6.8$ & $2.2 \pm 0.4$ \\
\hline 1421 & & $(\mathrm{smS})$ & Middle Buntsandstein / Solling & $30.6 \pm 8.9$ & $2.4 \pm 0.5$ \\
\hline 1463 & & $(\mathrm{smH})$ & Middle Buntsandstein / Hardegsen & $24.2 \pm 4.1$ & $3.1 \pm 0.4$ \\
\hline 1510 & & $(\mathrm{smDW})$ & Middle Buntsandstein / Detfurth alt. sequ. & $24.4 \pm 3.5$ & $3 \pm 0.4$ \\
\hline 1542 & & (smDS) & Middle Buntsandstein / Detfurth & - & - \\
\hline 1600 & & $(\mathrm{smV})$ & Middle Buntsandstein / Volpriehausen & - & - \\
\hline
\end{tabular}

Calculation based on computed heat-flow value of $74.2 \mathrm{~mW} / \mathrm{m}^{2}$ (Gt Ss $1 / 85$ borehole). 